\title{
13
}

\section{Competition, collaboration and consumption: early music printing in Seville}

\author{
Iain Fenlon
}

\section{Introduction}

By the late fifteenth century, Seville was the most densely populated and prosperous city in Castile. Occupying a strategic position on the banks of the Guadalquivir, at an important crossroads between the Atlantic and Mediterranean maritime trade routes, the city had developed into a major entrepôt for the exchange of a wide variety of commodities during the late middle ages. As the emergent centre of Andalusia, a largely agricultural region and since the reconquest from the Moors in the middle of the thirteenth century effectively its capital, Seville exported wool and fish to both northern and southern Europe while importing mostly finished goods including cloth. ${ }^{1}$ Links with Mediterranean countries through the Straits of Gibraltar, and with Portugal, France and the Low Countries via the Atlantic, brought Seville into contact with other major European trading centres, including Paris and Antwerp, two major centres of the book trade. Imports from Lyons were transported down the Rhône and then distributed via the major cities along the eastern seaboard of Spain, while Venetian books were transported along a safe route through the terraferma to Milan, capital of Spanish Lombardy, and then to Genoa (after 1528 formally a satellite of the Spanish Empire), and from there across the Mediterranean to Barcelona and Valencia.

As a result of Seville's cosmopolitan character and commercial opportunities, greatly increased by the import of silver, merchants from elsewhere in Europe had settled there in considerable numbers from the beginning of the sixteenth century. The largest foreign community came from Genoa, whose prosperity was critically dependent upon two elements: Spanish trade with the Indies, and the wealth of Italy. As Fernand Braudel put it: 'we must imagine the hundreds, perhaps thousands of Genoese merchants of various status, humble clerks, shopkeepers, go-betweens, commission agents, who peopled their own city and all the cities of Italy and Sicily. They were solidly established in Spain, at every level of the economy, in Seville as well as in Granada'.2 To Braudel's list of mercantile occupations should be added those in the printing and publishing trade, while to the Genoese should be added the French and Flemings who had also arrived in Seville in large numbers, to the extent that two quarters in the parish of Santa Maria la Mayor, close to the Cathedral, were popularly known as the 'Barrio de Génova' and the 'Barrio de los Francos'. ${ }^{3}$

These two 'nations' were to prove crucial for the establishment of the first printing presses in the city. The concentration of capital, much of it provided by Genoese bankers, and easy access to the international trade arteries which fanned out across the ocean as well as inland, made Seville an attractive location for the fledgling trade. ${ }^{4}$ A group of four native German printers called the Cuatros Alemanes Compañeros began to issue books in $1490,{ }^{5}$ their font for printing chant notation was used for the first time in the Manuale 
Toletanum. ${ }^{6}$ In addition to liturgical books, the Compañeros also catered for the related market for basic music-theory manuals, including the elegant editio princeps of Durán's Lux bella. ${ }^{7}$ Other Sevillian printers also produced manuals with woodcut notation in the first decades of the sixteenth century, including two editions of Alonso Españon's Introdución, printed by Pedro Brun, an anonymous Arte de canto llano, and a further edition of Durán's treatise. ${ }^{8}$ Such elementary didactic manuals clearly found a ready sale among the Sevillian clergy, who also constituted much of the market for liturgical books. At about the same moment that the Cuatros Compañeros began printing, Meinardo Ungut and Stanislao Polono arrived in Seville from Naples. ${ }^{9}$ Among the more than seventy titles which they produced in the nine years of their joint enterprise were a number of liturgical books, some with chant notation, including the Franciscan Processionarium of 1494 (see Figure 13.1). More than any other single incunable, this established the concept of a book of printed music in the Spanish trade. ${ }^{10}$

ec cosoittrores cius in capucijs cam eo Cumq5 ao me

(tum capiculi puenerit. Itans verfo vulcu ao crucificú oicac bumilivoce hanc ozarionem.

Etiones nras quefum ${ }^{9}$ oomine afpiranoo (ल) ṕneni r aoiuนāoo plequere: ot cücta nr̃a (2) 3 opatio ate femp icipiar $z \mathrm{p}$ te cepta finiat (1) (1) (1) per rpaiftum oominum noftrum. Fmen. L Qua ozatió cermiats per rṕm. Cạcosin

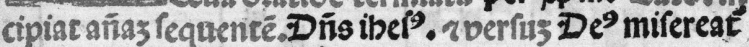

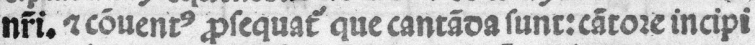
reantiphonas rocrius. Fo manoati antipbona.

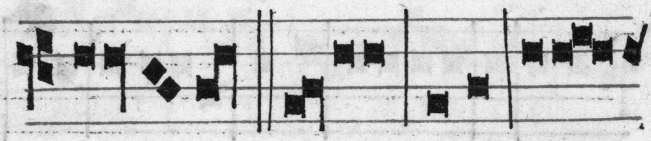

Omi nus ibe fusportä; cena

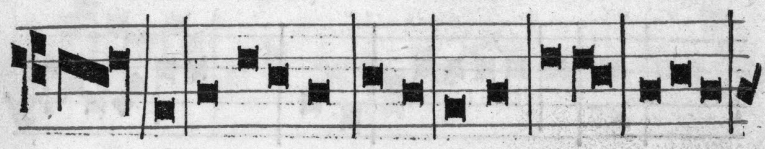

ui $t$ cũ oifcipulis fu is la uit peoes $c$ oนti
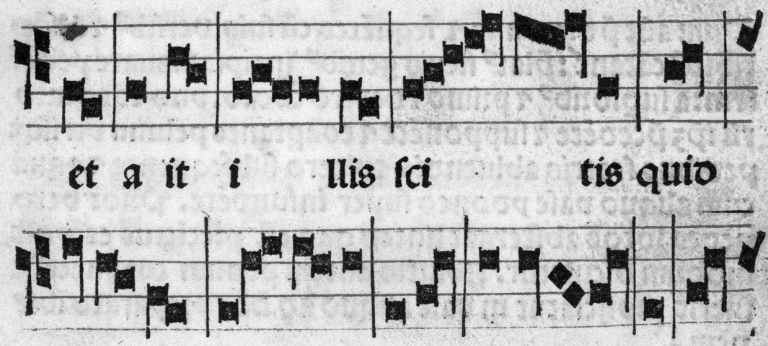

fece rim vo

bisego oomi nus $q$ ma

01

Figure 13.1 Processionarium ordinis fratrum praedicatorum (Seville: Ungut and Polonus, 1494), fol. d1 . Source: Madrid, Biblioteca Nacional de España. Inc/1268. 
Jacopo Cromberger, probably born in Nuremberg, came to inherit the business of the Compañeros at the end of the century, and between late 1503 and his death in 1528 he dominated the Seville trade. ${ }^{11}$ More than two-thirds of the editions printed in the city during this period were produced in Cromberger's workshop, while a further twenty percent came from the presses of his colleague and sometime collaborator Juan de Varela. ${ }^{12}$ It is not known when Jacopo obtained the privilege for printing all liturgical books in the diocese of Seville, but he retained the monopoly until his death. ${ }^{13}$ As part of his inheritance, Cromberger acquired at least three fonts from the stock of the Compañeros Alemanes, and eight from the workshop of Ungut and Polono. ${ }^{14}$ Among the latter was the music font for printing chant notation in liturgical books, which the two collaborators had used in their processional of $1494 .{ }^{15}$ This was used by Cromberger in his masterpiece of liturgical music printing, the Missale secundum usum alme ecclesie Hyspalensis which survives in three copies, of which one is printed on vellum and expertly illuminated for an unidentifiable patron. ${ }^{16}$ He also used it elsewhere, notably in his edition of the Franciscan Processionarium. ${ }^{17}$

At Cromberger's death, control of the family press passed to his son Juan. Under his ownership, editions of liturgical books continued to be produced for dioceses in Andalusia and southern Portugal, while under the Seville monopoly which passed to Varela at least three editions of the Seville missal were produced. ${ }^{18}$ For these Varela made use of the font of chant types which was passed on to him by Jacopo Cromberger in 1528, who had obtained it, in turn, from Polono in 1503. These books were evidently widely circulated, not only in Spain but also in the New World. ${ }^{19}$ Varela also came into possession of the types and ornaments of the press of the Cuatro Compañeros. Following Juan Cromberger's death in 1540, the press entered into decline, its list characterised by extraordinary conservatism, and its presswork of inferior quality. ${ }^{20}$ In the increasingly difficult environment for Sevillian printers working in the middle decades of the century, the more interesting developments in music printing and publishing, as in other areas of the trade, are to be found elsewhere, beginning in the 1540s.

\section{Juan de León in Seville}

In 1532, a contract was drawn up between a printer Juan de León, and Juan de Virida, and in the same year a separate document, which refers to someone of the same name as a Frenchman, suggests that he was a specialised punch-cutter. ${ }^{21}$ In another archival notice of 1525, a printer named Juan de León, then working in Seville, was connected to the production of playing-cards, traditionally a ready source of income for jobbing printers. ${ }^{22}$ Although it is far from certain that all these references are to one and the same person (the name is common), ${ }^{23}$ it is possible that one or all of them are the earliest documentary references to the printer who later set up in business in the same city.

Any aspiring craftsman taking such a decision would be immediately burdened with considerable debts unless supported by private means or wealthy patrons. Although the presses themselves were not expensive, matrices, types and type-metal were costly and often had to be bought from itinerant artisans or directly from abroad, since even the major printers in Spain did not own punches. ${ }^{24}$ Many of the typographical materials that Juan de León was to use throughout his career were obtained from the 'impresor' (in practice probably a bookseller and publisher) Gaspar Zapata, who had caused them to be used in five books printed in 1544, including a collection of Latin poems which ends with an epigram 'In laudem typographi' in praise of Zapata. ${ }^{25}$ The nature of the relationship is not clear (Juan may have bought the materials from Zapata outright, or had even planned to go into 
partnership with him), but within the year the text fonts, initial letters and other decorative elements from Zapata's books were being used in Juan's own titles.

This was not the only expense for someone fresh to the business. Quite apart from the cost of typographical materials, sufficient space had to be rented or bought to accommodate the workshop, and to house the employees who were to work there, including the black slaves who were often put to work as beaters and pullers. ${ }^{26}$ Wages, food, ink and above all paper, the most expensive element of producing a book, had to be bought. Since so little paper was produced in Spain, much of that used by Sevillian printers was imported from Italy and then sold through Genoese merchants in the city. ${ }^{27}$ The papers used by both Juan de León and his successor Martín de Montesdoca carry marks that were commonly found in paper produced throughout Italy, if not Europe. ${ }^{28}$ One disadvantage of this supply chain was that unless some form of discount had been agreed, local printers and booksellers did not have a competitive edge over foreigners whose books were imported, and since they also lacked sufficient access to international export markets, their output was essentially aimed at a largely national readership at best, secured through networks and the book fairs in Medina del Campo and elsewhere. Although there was always the possibility of export to the Indies, Juan de León's main markets were local and regional, principally the cities of Andalusia and Portugal, though some of his books were bought by those operating elsewhere in the peninsula.

In practice, most Spanish printers were also booksellers, and their retail premises were filled with editions produced by other members of the trade as well as imported books. The inventory of Jacopo Cromberger's property, drawn up in 1529, reveals that much of his stock came from elsewhere, including substantial imports from Lyons, Antwerp and Venice. ${ }^{29}$ While it is doubtful that Juan de León's networks were as extensive, his own books did reach beyond his most immediate markets. When a legal contract was drawn up in 1556 in connection with the lease of the premises in Burgos of the Florentine printer and publisher Juan de Junta, son of the famous Florentine publisher Filippo di Giunta, its stock of more than 15,000 books, representing 1,583 titles, contained many editions produced elsewhere in Spain, including at least four editions printed by Juan de León: the quarto edition of Juan Bermudo's Declaración de instrumentos musicales (1549), Mudarra's Tres libros de música (1546), the Tractado de la sphera by Johannes de Sacrobosco in the Spanish translation by Hierónymo de Chaves (1545) and the Summa de philosophia by Alonso de Fuentes (1547). ${ }^{30}$ Nonetheless, while Mudarra's Tres libros travelled to the north of Spain, there is no evidence that any of the vihuela books (or indeed any music printed in Spain in general) was exported to the imperial territories in Flanders, Lombardy or southern Italy. Although the print runs for some music books were as high as one thousand copies, the market was essentially regional if not national, even for books produced in cities with populations as large as those of Seville or Valladolid. Penetration of Spanish markets by foreign printers was considerable, and affected every aspect of the trade. Liturgical books were often printed abroad, commissioned from Venetian, Parisian and Lyonnais printers by syndicates of Spanish merchants and booksellers. Much imported polyphonic music came along these same routes, above all from Venice via Genoa, and from Lyons down the Rhône valley. ${ }^{31}$

Juan de León evidently did not have either the resources or the necessary powerful ecclesiastical patrons to enter the lucrative market for liturgical books; whatever the reason, he left this aspect of the Sevillian trade to the Crombergers and Juan de Varela. Instead, he adopted the strategy, common among many small provincial printers, of oscillation between the printing of short and technically undemanding volumes and the production of 
more substantial ones, in order to ensure that his press was not left idle. ${ }^{32}$ This procedure also meant that income from more saleable and popular titles could be set against the cost of larger projects which took longer to mature and generate a return. Of the six editions that Juan de León is said to have produced in the first year of his career, only three are known to survive: the Historia imperial by Pedro Mexia, Hernando del Pulgar's Coplas revulgo glosadas and the influential and much-reprinted short Tractado de la sphera by the thirteenth-century astronomer Johannes de Sacrobosco. ${ }^{33}$ In many ways these three titles set the style and tone of Juan's editorial policies, not merely in relation to the typographical features of his books, but also in terms of their reflection of Sevillian humanistic scholarship, emphasised by the use of an Italic font, still a comparable rarity among Spanish printers. Although the last two of these books, and particularly Sacrobosco's treatise, were well established in the Spanish market, Juan's edition of the latter marked a new departure by presenting it in translation by the local humanist scholar Hierónymo de Chaves. ${ }^{34}$ It presents the full range of Juan's text fonts, being set in two sizes of Gothic, with running heads and numeration of the scholia in Roman capitals, and occasional interventions of a small Italic font in the preliminaries and elsewhere. ${ }^{35}$ All three styles are deployed on the title-page, which frames the text with four woodcuts which re-appear, sometimes in variant form, throughout his career. The text is punctuated by a considerable number of woodcuts, some of which Juan was to call upon again. Entering into the spirit of the enterprise, he also devised an elaborate colophon (again displaying all three of his type designs), which calculates the year of publication according to a number of authorities, and gives the age of the author. ${ }^{36}$ The verso presents a woodcut of showing Hercules and the motto 'Labor omnia vincit' ('Industry conquers all'), an adaptation of a familiar Virgilian tag. ${ }^{37}$ This is apparently Juan's first printer's mark, which he used only in this first year, before it was passed on or somehow acquired by Martín de Montesdoca. ${ }^{38}$

In addition to liturgical books, for which there was a ready market, popular works in the vernacular had become something of a staple in the Seville trade by the middle of the century. ${ }^{39}$ Spanish editions of Pulgar's Coplas had been published since the late fifteenth century, and by the time that Juan de León came to print his own many others had appeared. Juan's modest octavo is largely printed in Gothic fonts of various sizes, though Italic makes a brief appearance in the colophon: 'Fue Impresso en Sevilla en casa de | | Iuan de Leon. A sancta Maria || de Gracia. Año de || $1545^{\prime} .{ }^{40}$ This is the earliest indication of the location of Juan de León's first workshop in the city, but by the next year he had moved to the parish of Santa Marina, located near the northern edge of the city. Most of the pressmen were concentrated to the south, close to the Cathedral and the commercial centre of the city; Santa Marina, by contrast, was largely inhabited by poor silk workers, mostly from Lyons. If the Pulgar edition is undemonstrative in appearance, Pedro Mexia's Historia imperial is altogether more imposing. Set in Gothic type arranged in two columns, with marginal notes in Roman, it comes with an elaborate title-page in which the text is framed by four woodcuts. Here the two side blocks incorporating medallion heads surrounded by laurel wreaths were specially cut for the edition and do not appear elsewhere in Juan's output. In the centre of the upper register there is a woodcut image of the arms of Philip II, dedicatee of the volume. There is some use of Italic scattered through the work, including the paratexts which also contain a full-page woodcut of Julius Caesar. ${ }^{41}$

Both Hierónymo de Chaves and Pedro Mexia were local men, the first a mathematician, astrologer and cosmographer who later became the piloto mayor of the Casa de Contratación in Seville in succession to Sebastian Cabot, the second a humanist and historian who went on to be appointed as the official court chronicler to Charles V. ${ }^{42}$ While Chaves' 
translation of Sacrobosco's Tractado is the first to appear in Spanish, Juan's edition of Mexia's Historia imperial is the second edition of a work that first appeared from the presses of another local printer, Domenico de Robertis. It evidently enjoyed considerable success, being reprinted by other printers both in Spain and north of the Alps. ${ }^{43}$ This concentration of editorial effort on writers living and working in Seville was extended in the following year when Juan made the decision to print Alonso Mudarra's Tres libros de música. ${ }^{4}$

\section{Alonso Mudarra, Tres libros (1546)}

Mudarra had grown up in Guadalajara, where he received his musical education and was salaried as a vihuelist in the household of Diego Hurtado de Mendoza y Luna, third Duke of Infantado. ${ }^{45}$ In 1529, when he would have been about nineteen years old, Mudarra may have travelled to Italy in the company of Inigo Lopez de Mendoza, Marqués de Santillana, as part of an entourage travelling to Bologna to attend the coronation of Charles V. There were plenty of other opportunities to be exposed to the influence of foreign music and musicians, and in the magnificent palace which the Dukes of Infantado had constructed at the end of the fifteenth century, Mudarra would have had plenty of opportunity to encounter them. Charles V was a guest there in 1526, 1528 and again in 1535 en route for Barcelona to inaugurate the Tunis campaign, and among other visitors who may have been accompanied by musicians was Francis I. ${ }^{46}$ By the time that Mudarra came to compile the Tres libros, almost certainly begun during his time in Guadalajara, his knowledge of foreign repertories, including Italian madrigals, was extensive.

Mudarra was appointed as a canon at Seville Cathedral in late October 1546, just two months before Juan dated the colophon of the Tres libros. ${ }^{47}$ As such he joined the wealthy ecclesiastical aristocracy of the city; the canons lived well, many found the time to accept university appointments, and beyond attending services had few duties. Mudarra was evidently highly cultivated. At his death in 1580 an inventory was drawn up of his estate. It includes a collection of 117 books, a middle-sized library for someone of his class and occupation, which includes a number of titles which might well have been printed by Juan de León: Mexia's Historia imperial, the Crónica del Pero by Cieza de León, the Chronografía by Hierónymo de Chaves and the Summa de filosofia by Alonso de Fuentes, all of which were printed by Juan during his Seville years. In the midst of these there are just two music books: the Arte ingeniosa by Melchior de Torres, and a 'printed book of vihuela tablature' ('libro de cifra de vigüela ympresso'), which is almost certainly a copy of Mudarra's own Tres libros. ${ }^{48}$

As the full title of his vihuela book suggests, its contents are organised by genre. ${ }^{49}$ Six pieces are for four-course guitar (the earliest pieces for the instrument to appear in print, preceding those in Melchior de Barberis' Intabolatura de lauto by two years), while Tiento IX is notated for organ or harp. ${ }^{50}$ This, the first appearance of this type of tablature in print, consists of fourteen lines and fifteen spaces, with the note to be sounded indicated by a single symbol ' $\mathrm{I}^{\prime} .{ }^{51}$ Throughout the rest of the book three mensuration signs $(\phi, c, \Phi)$ designate the tempo of each piece as fast, medium or slow, and the preface breaks new ground by including a discussion of plucking techniques. ${ }^{52}$ Another innovation involves placing the circumflex sign over the ciphers that are to be sustained in performance. ${ }^{53}$ Mudarra's collection is a revealing barometer of one professional's approach to performance, and as such an important moment in the sequence of published vihuela books, notwithstanding its small format and modest appearance on the page in comparison to Milán's El maestro or Fuenllana's Orphenica lyra. 
In terms of its design, Mudarra's Tres libros is in landscape quarto format, as is Luis Narváez' Los seys libros de Delphin, so as to create a manageable pocket-sized book instead of the upright format which was to become the norm for vihuela tablatures. ${ }^{54}$ Although the Narváez volume may well have been Juan's model in terms of its appearance, the format of the Tres libros also perhaps reflects Mudarra's contact with Italian and French editions for plucked strings. Then there is the arrival of a new printer's mark, which incorporates the motto 'SOLI DEO HONOR ET GLORIA', which does however carry a more polemical significance. ${ }^{55}$ This recurs in a number of Juan's later publications, including all his other music editions; here it is used on both the title-page of the volume as well as on the independent title-pages of the second and third books, framed in all cases by the same decorative borders. Except for the colophon, which is set in Juan's Gothic type, the text is printed in Roman.

For the tablature itself, Juan opted for a technologically simple solution. Eschewing the complications of Milán's El maestro, which is printed in red-and-black inks requiring at least two formes and two runs through the press, or Narváez' Les seys libros which is printed by triple impression, Juan settled on a single colour of ink and two fonts. While the ciphers, on a six-line stave with rhythmic symbols above, are printed with independent pieces of type, the vocal lines (in mensural notation) in the Libro tercero are also produced in the same way, making this the first example of music printed by the single-impression method in Spain. The elements of the pieces in guitar tablature, on four lines, are also printed from single sorts. ${ }^{56}$ This method, which both reduced the cost of the book, and simplified the production process, was later used to print the tablature books of Valderrábano and Pisador. ${ }^{57}$

Juan's music types are new: the ciphers are not cast from the same matrices as those used in Les seys libros, and Mudarra's system uses a rounded number ' 2 ' rather than the more common and angular ' $Z$ ' used in the books of Milán and Narváez. Since the music fonts do not recur in Juan's later books, nor did he pass it on together with his other materials to Martín de Montesdoca, they may have belonged to Mudarra, who could have brought them with him from Guadalajara; this might explain how the book was ready to be printed so soon after his appointment at Seville Cathedral, as well as the subsequent disappearance of the types. Unfamiliarity with both the material and the process is clear from the result, since Juan evidently had difficulty in printing the volume. The finished text contains a good number of errors in its pagination, the arrangement of the gatherings and at a more detailed level in the musical notation itself, suggesting that Mudarra did not attend the press, as was common practice, and that Juan, having had no previous experience with setting tablature, was severely challenged by the book's technical requirements. ${ }^{58}$ While it is true that compositors did not have more difficulties with assembling music types than they had with other languages with which they may have been unfamiliar, tablature notation presented particular challenges, since it was set not vertically like mensural or text types, but horizontally, line by line, using seven rows of symbols.$^{59}$ Perhaps again following the examples of Milán and Narváez, whose books include illustrations that resonate with humanistic themes, Juan enlivened the text with four woodcuts showing Mercury playing on an instrument made out of a tortoise shell, the Old Testament prophet Elisha accompanied by a vihuelist, an image of King David, and the so-called 'emblem of peace', a plumed helmet within a circle accompanied by the text 'Ex bello pax ex pace concordia ex concordia musica constat' ('Peace is established from war, concord from peace, and music from concord') ${ }^{60}$ Most of the decorative elements came out of Juan's stock, and had been used many times before. 
Mudarra's Tres libros represents an ambitious attempt by a printer unused, and to some extent unskilled in producing books of this kind, to enter a market that had already been inaugurated by the tablatures of Milán and Narváez. Once thought to have been an exclusively courtly instrument, the preserve of the educated elite, the vihuela and the printed books of music for its practitioners are now recognised to have had a much wider audience. As John Griffiths has eloquently written:

[...] the simplicity of vihuela tablature, the fact that it permitted sophisticated music to be played without requiring extensive prior musical training, and the size of the editions in which it was printed, all suggest that it was one of the principal ways in which the musically untrained bourgeoisie was able to enrich their musical experience within the domestic environment. ${ }^{61}$

The Tres libros is also part of a more general pattern. Printing music was for all Spanish printers merely a minor aspect of their general business, and none of them produced more than one book of music for the vihuela. Following his edition of Mudarra's tablature, Juan de León returned to more normal fare, printing works by Pietro Aretino and Alonso de la Fuentes in 1547, and by Sacrobosco (another edition of the Tractado) and Hierónymo de Chaves in $1548 .^{62}$

\section{Juan de León in Osuna}

Nicolao de Albenino's Verdadera relación, published in 1549, was the last book to appear from Juan's workshop in Seville before he was appointed as printer to the newly established University of Osuna, founded by Papal Bull in late 1548, and to its patron, Juan Téllez-Girón, fourth Count of Ureña. ${ }^{63}$ This new situation and the opportunities that it brought evidently encouraged Juan to re-configure his editorial orientation. Of the six titles that he printed between his arrival in Osuna and 1555, when he disappears from view, four contain music notation: Juan Bermudo's three treatises El libro primero de la declaración de instrumentos (1549), his El arte tripharia (1550) and the final version of the first, El libro llamado declaración de instrumentos musicales, which appeared in 1555. It was also during the Osuna years that Juan printed a set of part books, the first to be produced in Spain: Juan Vásquez' Villancicos i canciones, with separate books for tiple, tenor and bass. ${ }^{64}$ For these he employed an Italic font for the texts, and again the music font which appears in the earliest two Bermudo treatises. ${ }^{65}$

Taken together these four publications seem to represent a determined attempt not only to print practical music for local consumption, something which Juan had already presumably envisaged with the Mudarra vihuela tablature; but also, in the case of the three Bermudo treatises, to make an impact as a printer-publisher of humanistic texts as befitted the status of a university printer, thus hoping to widen his market. This was undoubtedly in emulation of printers who had gravitated to university towns in the hope of minimising risk by catering to the local population of students and scholars. In Salamanca, the seat of the oldest university in Spain, Juan de Porras had achieved a measure of financial stability by printing academic texts, many of which are in Latin; these include many editions and grammars edited by Antonio de Nebrija, commentaries on the classics (particularly Aristotle), and the only edition of the work of William of Ockham to be printed in Spain. Less successful was Miguel de Eguía's attempt to establish a university press at Alcalá de Henares, where he had rather ambitiously brought out an anthology of Greek texts, possibly on commission. Such attempts to enter a niche market were brave. Juan's only 
attempt to issue a classical text in Latin was his edition of Valerius Flaccus' Argonautica (which indeed Miguel de Eguía had printed in Alcalá in 1523), with notes by the professor of rhetoric at the University of Osuna, and a proud colophon in Latin announcing Juan's official position. ${ }^{66}$ While the high degree of specialisation that now entered Juan de León's work can be observed in the output of Eguía, Porras and a number of other presses working in a variety urban centres, these usually contained a leavening of the professional classes, people who could be expected to buy books. ${ }^{67}$ It may have been an appreciation of the commercial limitations of his new environment that prompted Juan to continue as a bookseller in Seville while printing in Osuna. ${ }^{68}$ Nonetheless, although Osuna in the 1540s was hardly Salamanca, Valladolid or Toledo, it seems that he was able to attract the interest of ecclesiastical and religious patrons when, with the three titles that constitute Juan Bermudo's Declaración de instrumentos musicales, he embarked on the production of the most ambitious and technically demanding project of his entire career as a printer.

\section{Juan Bermudo, Declaración}

Bermudo, who came from a distinguished family from Éjica, entered an Observant Minorite monastery at the age of fifteen. After studying in Seville, he then moved to Alcalá de Henares where, in the College of San Pedro y San Pablo, an institution reserved for members of the Franciscan order, he read mathematics. ${ }^{69}$ The first edition of the Declaración is advertised as the first instalment of what had been conceived of as a treatise in four separate books. ${ }^{70}$ Its dedication, to João III of Portugal, may have been yet another exercise in optimism (booksellers and printer-publishers working in Seville had cultivated the Portuguese market with some success), but with his second publication, Bermudo's El arte tripharia, an abbreviated version of the author's intended treatise in three books, aimed at students of polyphony, plainchant and organ playing, the patronage nexus becomes a little clearer. This entirely practical guide, fully in keeping with Franciscan attitudes towards the role of music in devotional practice, was written for the nuns of Santa Clara in Montilla at the instigation of the abbess of the community, Doña Isabel Pacheco. It was not until 1555 that the definitive version of Bermudo's text was published, though even then the work was not complete. ${ }^{71}$ The earlier books consist of elaborations of material from El arte tripharia, to which a new fifth book dealing with composition prefaced by a laudatory letter from Cristóbal Morales was added, but a sixth book announced in the front matter was not included and never appeared. The complete publication is dedicated to Francisco de Zúñiga y Avellaneda, Count of Miranda, a prominent member of a local aristocratic family.

Some of the typographical materials used in the printing of the first edition of the Declaración had been used in Juan's Seville imprints. A good deal of new material also had to be prepared, including five woodblocks to print diagrams of some elaboration, and new fonts of music type. It would have been unusual for such a small printing operation to have cut the blocks in its own workshop (not even the Crombergers produced their own), and while it is conceivable that the music type was cast on the premises, it is unlikely that punches were cut or matrices struck there. ${ }^{72}$ In addition to the woodblocks which are used to print four of the music examples, three different music fonts are used. The first involves double-impression printing, with five-line staves made up of individual pieces of type and printed in red ink, and chant notation then added in black ink in a second run through the press. A second font is used for passages of mensural notation printed in a single impression from independent pieces of type. Finally, there is a single passage in tablature. El arte tripharia is altogether more modest in its requirements. Again there are some mensural 
music examples printed with woodblocks, but most of the polyphonic notation is executed with the same single-impression font that had been employed in the 1549 edition of the Declaracion, which is also the source of a number of the woodcut diagrams.

Some of these make a further re-appearance in the 1555 edition (see Figure 13.2), and woodcut music examples are also still presented there despite the clear intention to make it more 'modern' and 'humanistic' in appearance. This aim is clearly set out in the arrangement of its title-page, which advertises its humanistic associations typographically by now abandoning Gothic completely, and setting the text in one size of Roman and two sizes of Italic. ${ }^{73}$ This last is then deployed, unusually for a theoretical treatise which would normally be set with all the gravitas of traditional Gothic, throughout the body of the text, with headings in Roman, the only exception being the sonnet in the preliminaries, for which Gothic is used. ${ }^{74}$ Two fonts of single-impression music type are used: a larger font that Juan had already used in the 1549 Declaración and El arte tripharia, and a smaller one

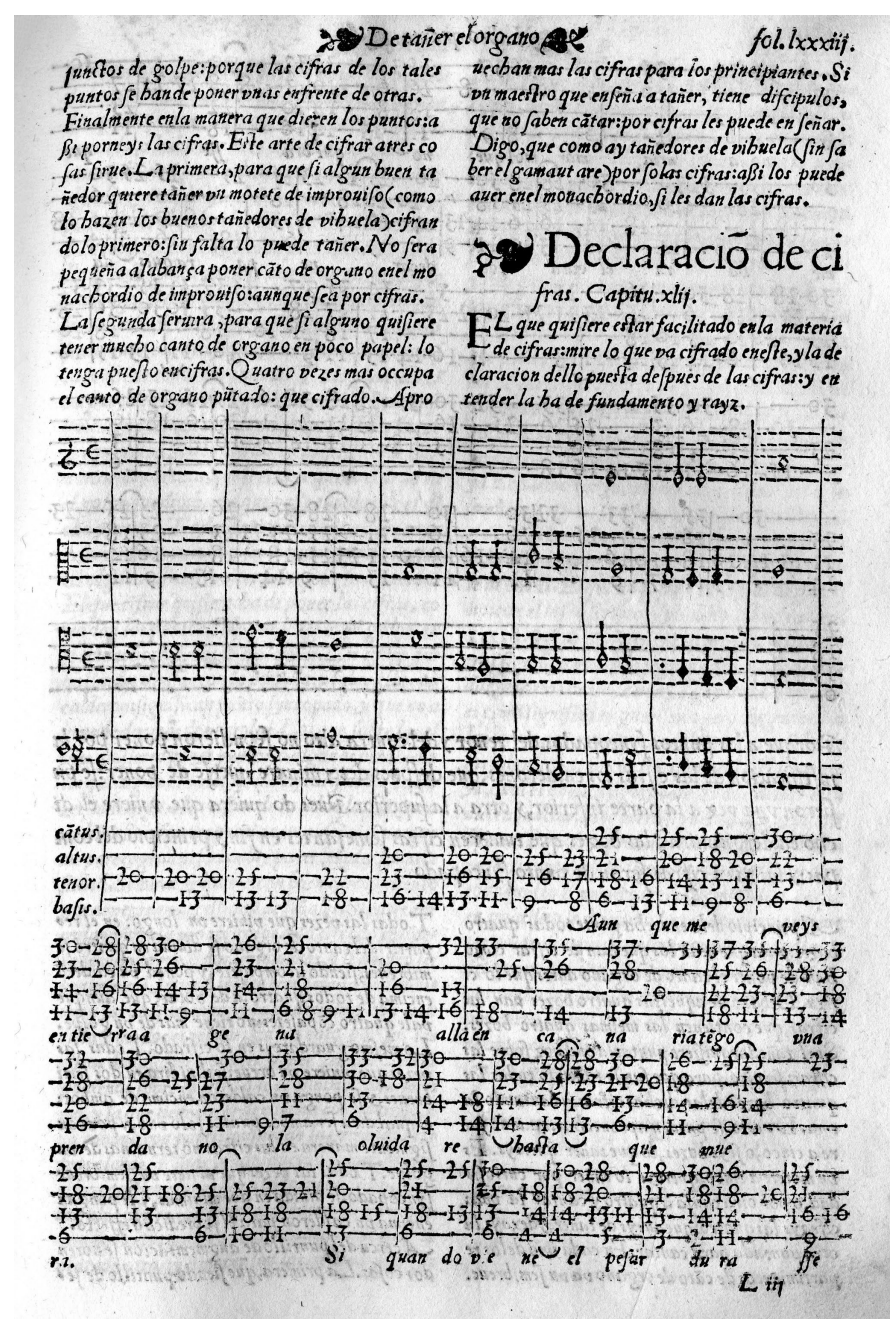

Figure 13.2 Juan Bermudo, Comiença el libro llamada declaración de instrumentos musicales (Osuna: Juan de León, 1555), fol. lxxxiij".

Source: New York, Hispanic Society of America (no shelfmark). 
that appears here for the first time. ${ }^{75}$ The larger page size of the 1555 edition seems to be the reason for some of the new types employed, including the woodcuts framing the text on the title-page, and the larger arrangements of the tablatures. ${ }^{76}$ Some of the woodblocks used in the 1549 edition were re-used, while others were re-cut to the same design.

In its finished form as presented in Juan's 1555 edition, Bermudo's Declaración is often described as the high point of sixteenth-century Spanish theoretical writing about music. To a considerable extent the text is rooted in medieval traditions, as can be seen in its references to Avicenna (an author also cited in the vihuela books by Luis Milán and Fuenllana), in its discussion of the beneficial effects of music on the soul and body (particularly as an antidote to pain), and in Bermudo's knowledge of Al-Fārābī's writings concerning the utility of music, where the familiar analogy between music and human nature is developed. ${ }^{77}$ Elsewhere the authority of Augustine is invoked, and many passages display familiarity with the notion of Aristotelian mimesis. ${ }^{78}$ Perhaps inevitably, the expected anecdotes about the power of music make regular appearances, demonstrating Bermudo's reading of Boethius and other authors in the Pythagorean tradition. If none of this is particularly surprising, there are also moments of considerable novelty. Among the many references to cosmic harmony as described by Boethius in the first book of the 1555 edition of the Declaración, to which Bermudo adds commentaries by Macrobius, Cicero, Pliny and St. Isidore, a new element is added, namely to attach planetary influence to each of the modes, an idea which is also present in Ramos de Pareja, whose Musica practica is most likely to have been his source. ${ }^{79}$ The final version of the Declaración also offers important insights into the techniques of both composition and instrumental performance in sixteenth-century Spain. In short, this essentially conservative document also displays an innovative imagination at work. ${ }^{80}$ An intellectually ambitious work, it is unparalleled among Spanish theoretical texts in the range of its reading of both ancient and modern authors, matched by the typographical sophistication which Juan de León attempted to bring to its fruition in print. A second edition of Bermudo's Declaración appeared from the press of Juan de León in the course of 1555. After that he disappears from view completely.

\section{Martín de Montesdoca and Miguel de Fuenllana's Orphenica lyra (1554)}

A few years earlier another Sevillian printer, Martín de Montesdoca, had begun work. His career and output are the subject of a classic study by Klaus Wagner, ${ }^{81}$ but there are two areas in which there is more to be said. The first concerns the sudden and remarkable shift in editorial politics, which occurred immediately after the appearance of the second version of Fuenllana's Orphenica lyra, a change which Wagner was certainly aware of, but which now can be more substantially explained. The second relates to the details and techniques of Montesdoca's printing of music, both before and after that shift.

His career as a printer begins in 1553 when his first book, the first part of Pedro Cieza de León's Chronica del Peru was published with a decorative title-page printed in red and black inks, which incorporates the arms of Philip II to whom the book is dedicated; the licence is dated 11 August $1552 .^{82}$ This was a successful start. In his account the author, who had settled in Seville after many years in the Americas, narrates the events of the Spanish conquest of Peru; within a year Montesdoca's text had been reprinted three times in Antwerp. ${ }^{83}$ Thereafter the exclusively secular texts that he printed were aimed at domestic and civic audiences, culminating in Miguel de Fuenllana's Orphenica lyra, the most typographically complicated vihuela book to be printed since Milán's El maestro. ${ }^{84}$ As with Narváez' Los seys libros del Delphin, the title itself deliberately evokes the humanistic ideals 
exemplified by the Italian concept of Orphic song. Between the granting of the licence and the dating of the colophon some fourteen months elapsed, a reflection perhaps of the technical complexities involved. ${ }^{85}$ Fuenllana's book finally appeared with an ambitious dedication to Philip II, a tactic which had been employed in Juan de León's edition of Mexia's Historia imperial, though in Fuenllana's case it may even have borne fruit, since following the arrival of Elisabeth of Valois as Philip II's third wife in 1559, the composer found favour at court, and shortly afterwards joined the entourage of musicians which she had brought with her from France.

As has long been recognised, the Orphenica lyra exists in two issues or variant editions, largely distinguished from each other by their first gathering. ${ }^{86}$ For the second issue this gathering was largely re-set, with a new title-page and a different sequence of poems in the paratexts. The music itself, set in nested type cast from no fewer than twenty-three matrices, begins on the first folio of the second gathering, and runs to the end of the volume. ${ }^{87}$ With one important exception the music gatherings are identical in both issues, perhaps suggesting that a certain number of sheets from the first printing were put aside in the hope that sales from the first edition would justify a second issue. This was a common strategy among printers. ${ }^{88}$ The exception however is significant, and concerns the title-page of the Libro quinto as it occurs in a number of copies of the second issue. In some copies the lower cartouche is blank, but in others it contains the motto 'Soli Deo honor || \& Gloria'. ${ }^{89}$ The title itself is framed by woodcuts of two caryatids to the left and right facing inwards rather than outwards, as they are in other copies. These changes are not merely accidental or insignificant, but relate to the meaning of Juan's adoption of a new printer's mark. ${ }^{90}$ (The complications of printing the book also resulted in errors. The proofreading, presumably carried out by Fuenllana himself, identified some of them, which were then corrected with printed pasteovers, ${ }^{91}$ but others remained.)

The original contract for the Orphenica lyra ordered a print run of one thousand copies. It has been estimated on the basis of surviving contracts that the average non-musical Seville edition consisted of 700 copies. ${ }^{92}$ This is large, not only in relation to local practice, but also by comparison with what little is known of Italian print runs for music editions. Nonetheless, it is not that unusual in the context of Spanish vihuela tablatures, some of which were printed in editions of 1225 (Cabézon) and even 1500 copies (Daza). ${ }^{93}$ Clearly the expectation was that the book would have a market outside Seville, including perhaps the New World. Commercial ambitions may have motivated Fuenllana to include not only a good deal of his own music, but also pieces by prominent contemporary Spanish composers, not only Guerrero and Morales as might be expected, but also a broad conspectus of work by French, Flemish and Italian composers. Madrigals by Arcadelt and Verdelot are prominent among the 'estrambotes a cinco y a quatro' of the fifth book, and motets and mass sections by Willaert, Gombert and Jacquet of Mantua are strongly represented in books two, three and four. ${ }^{94}$ Sales of the book were further complicated by the existence of fraudulent copies, which Fuenllana authorised his servant Juan Ruiz to collect on his behalf. ${ }^{95}$

As with Juan de León, most of the authors that Montesdoca published were local, while the texts which they provided fall into two chronological groups and generic categories. In an initial phase, which culminates in the printing of the second issue of Fuenllana's Orphenica lyra, the accent is upon secular works. This is then followed by a radical shift in the direction of devotional books, many issued as short pamphlets or more substantial theological treatises, many written by Domingo de Valtanás, a prolific author of religious texts, who was well-known locally as a popular preacher and a rigorous defender of daily communion (and in consequence frequent confession), a practice which he had been 
vigorously advocating for years. ${ }^{96}$ In the context of mid-century Spanish spirituality this viewpoint, together with his apologias in favour of the conversos and in defence of mental prayer, placed Valtanás in an isolated position. ${ }^{97}$ His arguments, outlined in detail in the Apologia de la frecuentación de la sacrosanta Eucaristía, were destined to fail, largely because his advocacy took place in the atmosphere of intolerance that followed the appointment of Fernando de Valdés as Archbishop of Seville in 1547. Professor of Canon Law at Salamanca University, and latterly Inquisitor General, Valdés approached the task of eliminating all forms of heterodoxy, particularly those supportive of the conversos, or sympathetic to Erasmian or Lutheran beliefs, with enthusiasm. In these circumstances, Montesdoca's extensive publication of Váltanas' works was both courageous and risky. Certainly it could arouse strong feelings among readers. In one copy of the Compendio de sentencias morales, the section headed 'De Martín Lutero' is heavily censored by a contemporary reader, with many passages crossed out and others excised completely, presumably in an independent fit of righteous anger. ${ }^{98}$

In late 1554 Montesdoca issued an edition of the Vita Christi and other works with a colophon dated 15 December. ${ }^{99}$ This was followed a few months later by the Doctrina christiana, the most ambitious of all Valtanás' catechetical writings. These were the first of no fewer than fifteen further titles by the Dominican that Montesdoca went on to issue (to which should be added a number of editions of which no copies are known to survive), all in the space of four years. ${ }^{100}$ This surge in Montesdoca's publication of devotional and theological texts did not stop there. In addition to Valtanás, he also championed the works of Francisco de Osuna, a Franciscan whose writings were among the most widely read books of popular religion in sixteenth-century Spain. Montesdoca printed no fewer than seven editions of Francisco's Abecedario espiritual, although no copies have survived. Significantly, all these were issued in 1554, precisely the year in which Montesdoca evidently determined to devote his press to octavo and quarto editions of short and accessible spiritual texts. Starting in the following year, he also printed a number of weightier theological disquisitions, this time in Latin, by another local author and fellow Franciscan, Pedro Fermosello, head of the Franciscan monastery in Seville. ${ }^{101}$

In the midst of this deluge of devotional literature, Montesdoca published, quite appropriately in view of his new editorial priorities, two collections of sacred music by local composers: Francisco Guerrero's Sacrae cantiones, a set of five partbooks, only the second collection to be published in this format in Spain (it is also by far the most elaborate), and the Agenda defunctorum by Juan Vásquez, who had been living in the city for some years. Of Montesdoca's three books of music, undoubtedly the most complicated from the technical point of view is the Orphenica lyra, often described in the secondary literature as being printed in two impressions, with the red layer executed first. It is more probable that it was set in one forme, and that a frisket sheet was then used to cover all the elements to be printed in red ink (both lines and ciphers), while the first layer was printed in black ink. Following this the black layer would then have been covered with a second frisket sheet, allowing the red layer to be added. The evidence for this procedure is the presence of small areas where black is printed over red, and others where the reverse is true (see Figure 13.3). ${ }^{102}$ The vocal parts are printed in mensural notation using woodblocks on a six-line stave.

\section{Montesdoca, Francisco Guerrero and Juan Vásquez}

In August 1555, Montesdoca entered into a legal agreement with Guerrero, now promoted to the post of maestro di capilla at Seville Cathedral, to print 750 copies of a book of his 


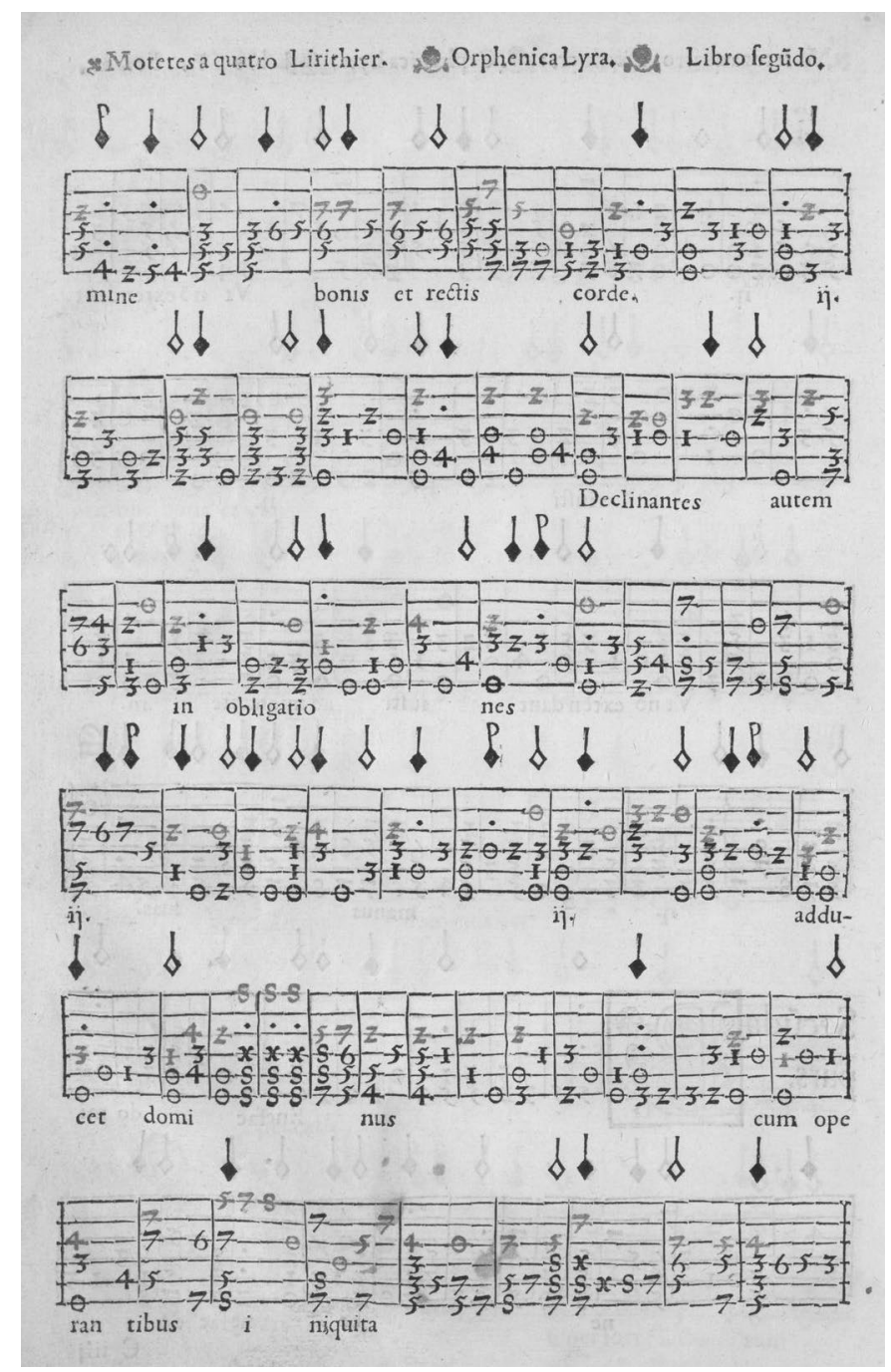

Figure 13.3 Miguel de Fuenllana, Libro de musica para vihuela, intitulado Orphenica lyra (Seville: Martín de Montesdoca, 1554), fol. $\mathrm{xx}^{\mathrm{v}}$.

Source: Wien, Österreichische Nationalbibliothek, SA.76.A.56.

compositions, as yet untitled, which was eventually published as the Sacrae cantiones. ${ }^{103}$ By contemporary Italian standards this print run for a set of partbooks is generous, though not even in Italy could there have been any sense of a 'normal' number of copies; in practice, the size of each edition printed in Spain would have been established by both the author (who was granted the licence) and the printer-publisher. In addition to the 'motetes a cuatro y cinco' specified in Guerrero's contract, the book was also to contain 'ocho maníficas, y más otros cosas que quisiéredes a mí dar' ('eight Magnificats, as well as other things which you might wish to give me'), but these never appeared. ${ }^{104}$ The title-pages of all the partbooks were ornamented with allegorical figures of Music playing a vihuela, and Geometry inscribing a tablet with calipers. ${ }^{105}$ For the rest, Montesdoca drew upon his existing stock of types (see Figure 13.4). ${ }^{106}$ 


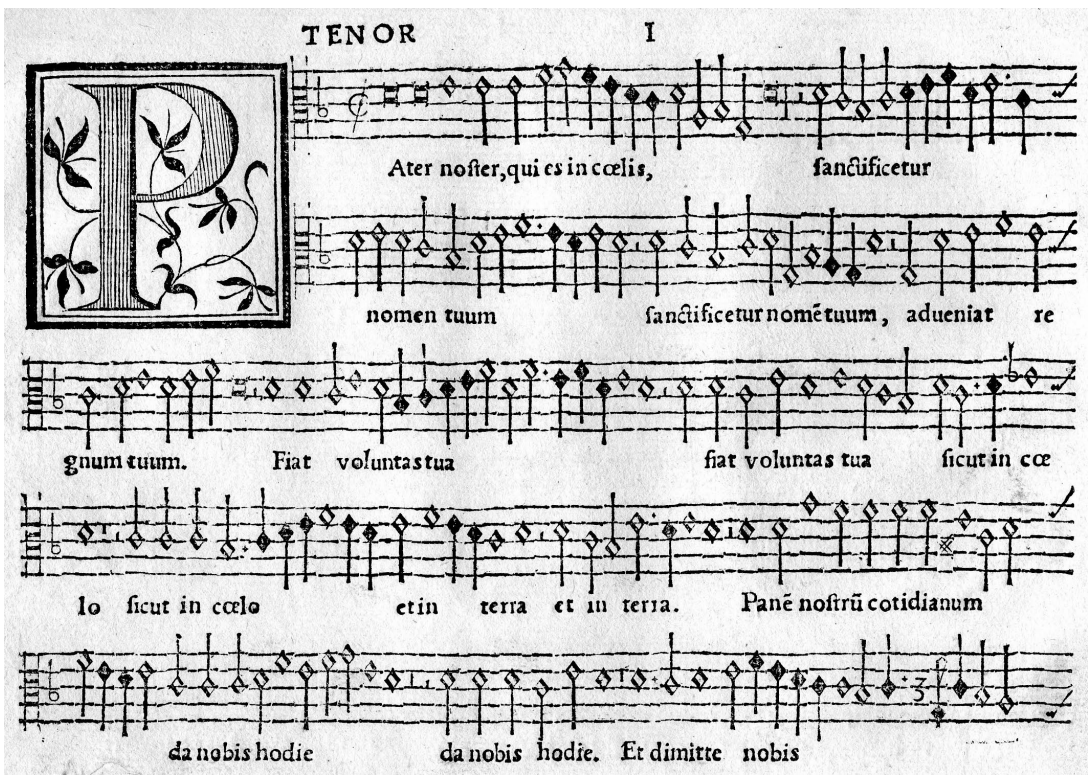

Figure 13.4 Francisco Guerrero, Sacrae cantiones, vulgo moteta nuncupate quinque vocum (Seville: Martín de Montesdoca, 1555), Tenor, fol. $1^{\mathrm{v}}$.

Source: New York, Hispanic Society of America (no shelfmark).

In the following year Montesdoca printed his last edition of music, the Agenda defunctorum by Juan Vásquez, who since 1551 had been on the payroll of Don Antonio de Zúñiga, son of the third Duke of Béjar, a local Sevillian aristocratic family which at least since the 1460s had maintained a chapel in their palace in the barrio of Santa Cruz. ${ }^{107}$ Vásquez is documented in the city on a number of occasions in the 1540s, years in which he was maestro de capilla of Badajoz Cathedral, and by 1551, when Juan de León printed the partbooks of his Villancicos $i$ canciones with a dedication to Zúñiga, he was evidently in the service of the family. ${ }^{108}$ An Agenda is a ritual book containing the texts and sometimes chants for common services such as baptism, wedding services and funeral rites, similar in function to Caeremonialia and Litaniae. Juan Vásquez' Agenda, which is entirely devoted to music for the dead, provides texts and music for six liturgical components: the invitatory, first, second and third nocturns, lauds and finally the mass for the dead. These structural elements are echoed in Victoria's Officium defunctorum of 1603, which, in turn, forms part of long tradition of stile antico requiem settings which persisted in Spain and Portugal for longer than elsewhere in Catholic Europe. ${ }^{109}$ In deciding to compile the Agenda, it is probable that Vásquez could have been motivated by the recently published polyphonic requiem settings by Morales. Guerrero may have been involved in the project; in August of 1556 he purchased a considerable amount of paper, as he had done the previous year for the publication of his Sacrae cantiones. ${ }^{110}$ For the Agenda, Montesdoca used a font of singleimpression mensural music type, and three fonts of text type: Roman underlaid to the music, and two sizes of Gothic for the remaining texts. ${ }^{111}$ He also incorporated two woodcut images of the Crucifixion, one large the other small, of the design commonly illustrated in missals. Not found elsewhere in his work, they are of a high artistic standard and may well have been borrowed from another printer. ${ }^{112}$ 


\section{Printing Communities and Music}

The impression created by what can be recovered of the activities of Juan de León and Martín de Montesdoca suggests both a reliance on new work by Sevillian authors as well as a certain degree of collaboration about technical matters within the printing trade. Most of Juan de León's authors were local men. Hierónymo de Chaves was born in Seville and worked there for most of his life, as did Pedro Mexia and Alonso de Fuentes. The same is true of the books published by Montesdoca, who began printing with the Chronica del Peru by Pedro Cieza de León, who had settled in Seville in 1551 and also went on to produce editions of Hierónymo de Chaves, Valtanás and Fermosello; all of these were then resident in the city. Taken into consideration with what can be reconstructed of patronage networks, which mostly involved members of the aristocracy, the image of Sevillian printing in the 1540s and 1550s (outside the dominant Cromberger operation) is of a tightly knit community of artisans and small-time entrepreneurs struggling to make a profit in difficult circumstances. Juan de León's business may have been crippled by the acute paper shortage which began in 1554 (a year in which he printed nothing) and lasted until 1555, when Bermudo mentioned that Juan was unable to print the sixth book of the Declaracion. In these difficult circumstances it is not surprising that typographical materials were sometimes shared. This is particularly true of ornamental material, which frequently passed from one printer to another, if only temporarily. Sebastián Trugillo, who ran a medium-sized workshop in Seville, occasionally borrowed woodblocks from both the Cromberger press and sometimes from Juan de León. ${ }^{113}$ Similarly, Juan de Varela appears to have shared a number of fonts with the Cromberger press, which also lent types from his stock to Varela, or at least passed them on to him. ${ }^{114}$ And a number of the woodblocks used by Montesdoca, including those involved in printing the title-pages of the Orphenica lyra, had been previously used in books produced in the workshops of Antón Alvarez and Juan de León. ${ }^{115}$

It is more than possible that the spirit of collaboration which connected the professional activities of Montesdoca, Juan de León and other printers working in Seville was, in turn, related to shared confessional sympathies, which are reflected in the work of the authors that they chose to print. Constantino Ponce de la Fuente, whose work Juan de León had published during the 1540s, before he became chaplain to Charles V, was appointed to a canonry in Seville Cathedral at the end of the 1550s, but was almost immediately caught up in the purge of suspected heretics inaugurated by Valdés, tried by the Inquisition and imprisoned. By 1559 his work had been placed on the Index, as had the writings of Erasmus, with whom Constantino had corresponded, and whose De octo orationis partium constructione Juan de León had published in Osuna. ${ }^{116}$ Closer to home, Gaspar Zapata, from whom Juan had obtained his types before starting work in 1545, was later tried by the Inquisition, as was Alonso Mudarra's brother Francisco, another canon of the local cathedral, who in 1548 was accused of heresy by the Roman Inquisition and imprisoned in the pontifical prison of Tor di Nona. ${ }^{117}$ Domingo de Valtanás, who became Montesdoca's main author from 1554 until the printer ceased activity four years later, did not fare any better. In 1559 Protestant conventicles were discovered in Seville, and two years later Valtanás was detained by the Inquisition, and subsequently condemned to perpetual confinement in the remote monastery of Santo Domingo de las Cinco Llagas in Alcalá de los Gazules (Cádiz). By then the censors had been at work, and his Vita Christi, which Montesdoca had printed, had been placed on the Pauline Index.

Beyond the texts which both printers selected for publication, the most explicit demonstration of Protestant sympathies can be seen in Juan de León's decision, beginning in 
1546, to introduce a new and surely contentious printer's mark. By the time he came to print Mudarra's Tres libros, his Hercules mark had passed on to Montesdoca, who used it throughout the rest of his career in conjunction with his more familiar second mark. ${ }^{118}$ In its place Juan now adopted a new image, consisting of Golgotha surmounted by the three nails used at the Crucifixion within a circle surrounded by the motto 'SOLI DEO HONOR ET GLORIA' and the phrase 'Sola fides sufficit' (see Figure 13.5). ${ }^{119}$ The concept of 'Soli Deo [Honor et] Gloria', one of the five solae of the Protestant Reformation, fundamental to the doctrine of salvation as adopted by the Lutheran and Reformed branches of Protestantism, stood in opposition to the teachings of Catholicism, which encouraged veneration of the Virgin, the saints and the angels and archangels; by contrast, 'Soli Deo Gloria' taught that glory was due to God alone. Furthermore, the phrase 'Sola fides sufficit' ('faith alone suffices'), although a direct quotation from Thomas Aquinas' Corpus Christi hymn Pange lingua, could serve as a sign to fellow Protestants in the wake of Luther's proclamation of justification by faith alone. The addition of the words 'Sola fides sufficit' further strengthens the Protestant associations of Juan de León's printer's new mark, since 'Sola fide', one of the three original solae, refers to the doctrinal issue that was central for the reformers; Luther wrote: 'isto articulo stante stat Ecclesia, ruente ruit Ecclesia' ('if this article stands, the church stands; if it tumbles, the church also falls'). ${ }^{120}$

Following his departure from the scene in 1559, Montesdoca's types, including his music font, decorative initials and his Hercules printer's mark, were acquired by Juan Gutiérrez, who went on to use them to produce the partbooks of the Recopilacion de sonetos $y$ villancicos by Juan Vásquez. ${ }^{121}$ When Guerrero, arguably the most distinguished composer living in Spain (he was to spend the rest of his career at Seville Cathedral) published his next book of music, he turned to Venice. That decision is symbolic not only of the fragile condition of music printing in the peninsula in general, but also of the difficulties that had beset the Sevillian book trade in the 1550s, and which had a permanent effect. ${ }^{122}$ Guttiérez continued to print liturgical books after 1560, but Vásquez' Recopilacion turned out to be the last book of polyphonic music to be printed in Seville.

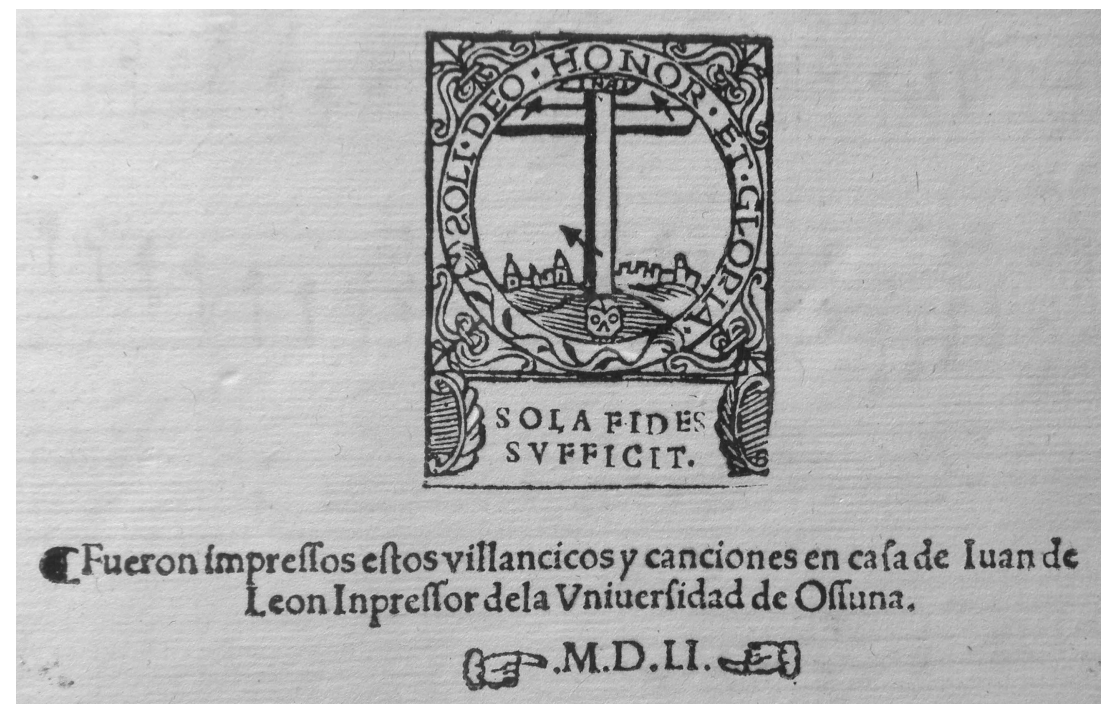

Figure 13.5 Juan Vásquez, Villancicos i canciones (Osuna: Juan de León, 1551), Baxo, colophon. Source: Palma de Mallorca, Biblioteca Bartolomé March, B88-A-25. 


\section{Acknowledgements}

I would like to thank colleagues and friends who have discussed aspects of this paper in detail, in particular Mario Armellini, Nicolas Bell, Marie-Alexis Colin, Marie-Pierre Dusausoy, Elisabeth Giselbrecht, John Griffiths, Neil Harris, Renata Pieragostini and Elizabeth Savage. Among the librarians who have facilitated the work I am particularly grateful to the staffs of the Biblioteca Nacional de España, the British Library, the Cambridge University Library, the National Library of Scotland, the Biblioteca Pública Provincial de Córdoba and the Biblioteca Universidad de Oviedo. A special debt of gratitude is due to John O'Neill and his colleagues in the Library of the Hispanic Society of America, and to Francisco Roldán of the Biblioteca March in Palma de Mallorca.

\section{Notes}

1 Chaunu, Séville et l'Atlantique, 1: 30-34; Ladero Quesada, La ciudad medieval, 75-103.

2 Braudel, Civilization and Capitalism, 1: 169.

3 Pike, Enterprise and Adventure, 1.

4 For general surveys of the sixteenth-century Sevillian book trade, see Domínguez Guzmán, El libro sevillano and Álvarez Márquez, La impressión.

5 Hazañas y la Ruá, La imprenta en Sevilla, 1: 20-21; Norton, Printing in Spain, 8-9.

6 Manuale Toletanum (Seville: Juan Pegnitzer, Magno Herbst and Thomas Glockner for Francisco Gorricio and Melchior Gorricio, 1494). See Restrepo, 'German-Speaking Printers', 54.

7 Domingo Marcos Durán, Gregorius Magnus. Lux bella, seu artis cantus plani compendium. Arte de canto llano, octo tonis artis musicae (Seville: Paulus de Colonia, Juan Pegnitzer, Magno Herbst, and Thomas Glockner, 1492).

8 The two editions of Españón's Introdución muy util y breve de canto llano were published by Pedro Brun in 1504 and c. 1506; see Norton, A Descriptive Catalogue, nos. 747 and 749. The Arte de canto llano was printed by Juan de Varela sometime after 1512; see Norton, A Descriptive Catalogue, no. 985. For the 1518 Cromberger edition of Duran's Lux bella, see Norton, A Descriptive Catalogue, no. 911.

9 Hazañas y la Ruá, La imprenta en Sevilla, 1: 27; Norton, Printing in Spain, 9-10.

10 Processionarium ordinis fratrum praedicatorum (Seville: Ungut and Polono, 1494).

11 Norton, Printing in Spain, 10-15; Griffin, The Crombergers, Chapter 2.

12 Norton, Printing in Spain, 15-19; Griffin, The Crombergers, 23-31.

13 Norton, A Descriptive Catalogue, 347-348.

14 Griffin, The Crombergers, 178.

15 Liber processionum secundum ordinem fratrum predicatorum (Seville: Ungut and Polono, 1494).

16 Missale secundum usum ecclesie Hyspalensis (Seville: Jacopo Cromberger, 1507). The illuminated copy is in the British Library, shelfmark C.36.1.11. See Norton, Descriptive Catalogue, no. 773.

17 Processionarium secundum morem ordinis predicatorum (Seville: Jacopo Cromberger, 1519). See Norton, A Descriptive Catalogue, 919.

18 Missale divinorum secundum consuetudinem sancta ecclesie Hyspalensis (Seville: Juan Varela de Salamanca). Griffin, The Crombergers, 50, notes editions of 1529, 1533, 1534, and 1537. Only three of these $(1529,1534$, and 1537) are listed in Wilkinson, Iberian Books, nos. 6413-6415.

19 Gembero Ustarroz, 'Circulación de libros', 167, records '3 misales según el uso sevillano' and '2 [3] processionarios sevillanos' inventoried at Cuzco Cathedral in 1546 and 1550, and '2 misales sevillanos' inventoried at Guatemala Cathedral in 1549.

20 Griffin, The Crombergers, 105.

21 Ibid., 169.

22 Gestoso y Pérez, Noticias inéditas, 21. Intriguingly, it is also recorded that on 17 March 1551, one Juan de León signed a contract to print two reams of playing-cards daily; ibid., 21.

23 Griffin, Journeymen-Printers, 90.

24 Cruikshank, 'Some Aspects of Spanish Book-Production', 6.

25 Moll, 'Gaspar Zapata'. Zapata subcontracted the work of printing these volumes to others, whose names do not appear in their colophons. 
26 Seville had the largest Spanish population of black slaves. For their involvement in the printing trade, see Gestoso y Pérez, Noticias inéditas, 74; and Griffin, Journeymen-Printers, 156-157.

27 On the importance of paper imported from France and Spain for Spanish printers, see Valls i Subirá, La história del papel, vol. 1, and especially 2: 17-30.

28 The paper in the Madrid copy of Mudarra's Tres libros is watermarked with the common design of a hand from whose middle finger is extended a stem supporting a five-petalled flower. A variant occurs throughout some of the copies of Fuenllana's Orphenica lyra, while other common marks such as the 'pot' and 'oxhead' varieties are also to be found in the books of both printers.

29 Griffin, The Crombergers, 43-54.

30 Pettas, A Sixteenth-Century Spanish Bookstore, 117, 129, 142, 143.

31 For Lyons see Peligry, 'Les editeurs Lyonnais' and, for the importation of polyphonic choirbooks, Fenlon, 'Jacques Moderne's Choirbooks'.

32 Juan's rate of production suggests that he maintained a single press operated by just a puller, a beater and one other worker, probably himself.

33 Lost editions of Pedro Bovistan, El theatro del mundo, trata de las miserias del hombre; Pius II, Tractado llamado el sueño de la fortuna; and Constantino Ponce de León, Suma de doctrina christiana, are noted in Wilkinson, Iberian books, nos. 2210, 14951, and 15058.

34 Johannes de Sacrobosco, Tractado de la sphera ... nuevamente traduzido de latin en castellana por el bachiller Hieronymo de Chaves (Seville: Juan de León, 1545).

35 The sizes are as follows: Gothic ( $2 \mathrm{~mm}$ and $3 \mathrm{~mm})$; Roman (4 mm); Italic (2 mm).

36 Colophon: FVE IMPRESSO EN | | LA MVY NOBLE Y LEAL CIVDAD DE SEVILLA EN CASA DE || Juan de Leon, e nel Año || de la Incarna | | cion || de || nue | | stro Salva | | dor del 1545. Y de la creacion del Mun | | do segun los Hebreos. 5497 | | Segun Paulo Orosio 6595 | | segun los | | primeros padres de la yglesia. 6744 Segun el rey || don Al $=$ | fonso. / 8529 y de la $\mathrm{e}=\mid$ | dad del Autor de la presente || Obra. 22 || Virtus sine aduersario marcesit.

37 Virgil, Georgics, I, 145-146.

38 See Vindel, Escudos y marcas, no. 185. For further discussion see above, 309, 314, 319.

39 Griffin, The Crombergers, $11 \mathrm{fn} .45$.

40 Hernando de Pulgar, Coplas revulgo glosadas (Seville: Juan de León, 1545).

41 Pedro Mexia, Historia imperial (Seville: Juan de León, 1545), fol. 6v.

42 On Chaves and the Casa de la Contratación, see Serrera Contreras, 'La Casa de la Contratación', 141-176. For his broad intellectual interests, see the inventory of his library published in Wagner, 'A proposito de la biblioteca'.

43 Peeters-Fontainas, Bibliographie, record four editions published in Antwerp between 1552 and 1578, three at the press of Martín Nutius and later his heirs, and one by Pierre Bellère (nos. 783-786).

44 Alonso Mudarra, Tres libros de música en cifras para vihuela (Seville: Juan de León, 1546).

45 Roa Alonso documents the presence of Mudarra in the household of the Dukes of Infantado between 1523 and 1543; see Roa Alonso, 'Alonso Mudarra', 112-113, and the summary of his biography on 134-141.

46 Roa Alonso, 'Alonso Mudarra', 47-50. Francis I visited the palace in 1525, having been taken prisoner following his defeat at the battle of Pavia.

47 Roa Alonso, 'Alonso Mudarra', 168-169. The colophon of the Tres libros is dated 7 December 1546.

48 Melchior de Torres, Arte ingeniosa de música con nueva manera de avisos breves y compendiosos sobre toda la facultad della (Alcalá de Henares), various editions for which see Wilkinson, Iberian books, nos. 18587-18589. For the inventory of Mudarra's books, see Wagner, 'Los libros', Ros-Fábregas, 'Libros de música', and Roa Alonso, 'Alonso Mudarra', Anexos X and XI.

49 Brown, Instrumental Music, 1549/2.

50 Melchior de Barberis, Opera intitolata Contina. Intabolatura de lauto di fantasie, motetti, canzoni discordate a varii modi ... fantasie per sonar sopra la chitara a da sette corde ... libro decimo (Venice: Scotto, 1549).

51 Bordas, 'The Double Harp in Spain', 149, where it is also noted that although Mudarra intended to publish further works using this system, the project was unrealised.

52 Luis Milan, Libro de música ... Intitulado El maestro (Valencia: Francisco Diaz Romano, 1536), the earliest printed tablature for vihuela, uses verbal indicators to express tempo.

53 I am grateful to John Griffiths for these observations. 
54 Luis de Narváez, Los seys libros del Delphin de música de cifras para tañer vihuela (Valladolid: Diego Fernández de Córdoba, 1538).

55 See above, 309, 314, 319.

56 The measurements are as follows: vihuela tablature, stave $25 \mathrm{~mm}$ high; mensural, staves $13 \mathrm{~mm}$ high; guitar tablature, staves $15 \mathrm{~mm}$ high.

57 Enrico de Valderrábano, Libro de música de vihuela, intitulado silva de sirenas (Valladolid: Francisco Fernández de Córdoba, 1547); Diego Pisador, Libro de música de vihuela (Salamanca: Guillermo de Millis, 1552). In both cases, the gatherings using red and black inks are printed using the frisket method (see above, 315).

58 Roa Alonso, 'Alonso Mudarra', 213-218.

59 For the general point see Giselbrecht and Savage, 'Printing Music', 84-86, and for tablatures Griffiths, 'Printing the Art of Orpheus', 196-198.

60 This latter was to re-appear in the Villancicos $i$ canciones, fol. 2 in all parts.

61 Griffiths, 'The Transmission of Secular Polyphony', 323.

62 Pietro Aretino, Colloquio de las damas (Seville: Juan de León, 1547); Alonso de Fuentes, Summa de philosophia natural en la qual assi mismo se tracta de astrulugia y astronomia, \& otras sciencias (Seville: Juan de León, 1547); Johannes de Sacrobosco, Tractado de la sphera (Seville: Juan de León, 1548); Hieronimo de Chaves, Chronograhia o repertorio de los tiempos (Seville: Juan de León, 1548).

63 Nicolao de Albenino, Verdadera relacion de lo sussedido en los reynos e provincias del Peru (Seville: Juan de León, 1549).

64 Juan Vásquez, Villancicos i canciones a tres y a quarto (Osuna: Juan de León, 1551). See the introduction to Russell, Juan Vásquez, Villancicos i canciones, which however says little about typographical materials and printing techniques.

65 The Italic type measures $2 \mathrm{~mm}$, the music font $14 \mathrm{~mm}$. Elsewhere, including the title-page which also carries the coat-of-arms of the dedicatee Antonio de Cunniga [Zúñiga], various sizes of Roman are used.

66 Valerius Flaccus, Argonantica [sic] cum annotationibus Alphonsi Ayllorum Ossunensi academia latini sermonis professoris rhetoricum artificium explicantibus. Valerii vita ex libris Petri Criniti de poetis latinis. Colophon: Excudebat Iohannes Leoursaone in florentissima academia ann. 1553. Idibus Ianuarijs.

67 Griffin, The Crombergers, 11.

68 Gestoso y Perez, Noticias ineditas, 119, claims that León kept his shop in Seville open during the Osuna years.

69 Stevenson, Juan Bermudo, 1-2.

70 Juan Bermudo, Comiença el libro primero de la declaración de instrumentos (Osuna: Juan de León, 1549).

71 Juan Bermudo, Comiença el libro llamado declaración de instrumentos musicales (Osuna: Juan de León, 1555). For the gestation of the treatise see Freis, 'Becoming a Theorist'.

72 Griffin, The Crombergers, 132.

73 The Roman type measures $4 \mathrm{~mm}$ in height, the two sizes of Italic $3 \mathrm{~mm}$ and $2 \mathrm{~mm}$.

74 This is the work of 'un amigo del autor'.

75 The larger type measures $14 \mathrm{~mm}$ in height, and the smaller one $9 \mathrm{~mm}$. The stave heights are 10 $\mathrm{mm}$ (Books I-IV), and $13 \mathrm{~mm}$ (Book V).

76 These are $26 \mathrm{~mm}$ high.

77 Otaola González, La pensée musicale espagnole, 108.

78 Ibid., 201-202, 204-206.

79 Ibid., 234-236.

80 Ibid., 238.

81 Wagner, Martín de Montesdoca.

82 Pedro Cieza de León, Parte prima de la chronica del Peru (Seville: Martín de Montesdoca, 1553); see Wagner, Martín de Montesdoca, 61, bibliografía critica, no. I. As originally planned the Chronica was to be printed in four volumes.

83 Peeters-Fontainas, Bibliographie, I, nos. 254-256. The 1544 edition published by Steelsius and Laet as recorded in Wilkinson, Iberian books, no. 3311 is a ghost.

84 Miguel de Fuenllana, Libro de musica para vihuela, intitulado Orphenica lyra (Seville: Martín de Montesdoca, 1554).

85 The fifteen-year privilege is dated 11 August 1553, the colophon 2 October 1554. 
86 First noted by Anglés and Subirá when cataloguing the four copies of the Orphenica lyra in the Biblioteca Nacional in Madrid; see Anglés and Subirá, Catalogo musical, 3: 94-98, and Wagner, Martín de Montesdoca, bibliographia critica, nos. IV and VII. For a discussion of the terminology see Lindmayr-Brandl, 'Early Music Prints and New Technology', 247-248.

87 That is, fols. i-clxxiiij, gatherings A-Z8.

88 From among the many other examples, see Giovanni Botero, Relaciones universales del mundo ... primera y segunda parte (Valladolid: Heirs of Diego Fernandez de Cordova, 1599-1603), where this second issue of the first Spanish edition of Botero's text is composed of sheets of the first edition of 1599-1600 together with a new title-page carrying the coat-of-arms of the Duke of Lerma, to whom the book is dedicated.

89 Wagner, Martín de Montesdoca, Figure 3e.

90 For the mark and its meaning, see above, 309, 314, 319.

91 As in the copy in the Newberry Library in Chicago (VM 125.F95L), fols. clxvii and clxix.

92 Griffin, The Crombergers, 131.

93 See Griffiths, 'Printing the Art of Orpheus', 191. As is noted there, choirbooks and sets of part books intended at least in part for the Spanish market were printed in much smaller numbers.

94 Brown, Instrumental Music, 153-159.

95 Wagner, Martín de Montesdoca, 112, and Griffiths, 'Printing the Art of Orpheus', 190-191.

96 Civale, 'Domingo de Baltanás'.

97 Roldán-Figueroa, The Ascetic Spirituality of Juan de Ávila, 117-155, with a discussion of Valtanás' views on 150-152.

98 Córdoba, Biblioteca Pública Provincial de Córdoba 14/199 contains three tracts by Valtanás printed by Montesdoca in 1555, the Vita Christi, Concordancias de algunos passos difficiles de la scriptura, and Compendio de sentencias morales bound together in a contemporary binding. An early owner, 'Fr[ay] Thomas de la Fuente' (flyleaf inscription) may have been responsible for the savage censorship of the text of the Compendio (fols. $x x-x x i$ ). There is no evidence that the Inquisitors had ordered that specific sections of the text be expurgated.

99 Wagner, Martín de Montesdoca, bibliografía critica, no. VI, recording the unique copy in Madrid, Biblioteca Nacional R/1585. Palau y Docet, Manual, XXV, no. 349169, lists an earlier edition printed in June of the same year 'en casa de Martín de Montesdoca', of which no copies are known.

100 Wagner, Martín de Montesdoca, 66-81.

101 Wagner, Martín de Montesdoca, bibliografía critica, nos. XVI, XVII, XVIII, all printed in 1555.

102 I am grateful to Elisabeth Giselbrecht and Elizabeth Savage for discussing this point.

103 Francisco Guerrero, Sacrae cantiones, vulgo moteta nuncupata, quinque vocum (Seville: Martín de Montesdoca, 1555). See Wagner, Martín de Montesdoca, bibliografia critica, no. XIX. This title is not recorded in Wilkinson, Iberian Books.

104 For the contract, see Wagner, Martin de Montesdoca, 114-115, document 42.

105 Wagner, Martín de Montesdoca, fig.7a.

106 Gothic (4 mm and $5 \mathrm{~mm}$ ); Roman ( $3 \mathrm{~mm}$ and $4 \mathrm{~mm}$ ). The music type measures $11 \mathrm{~mm}$, and the formes are completed with single pieces of type and metal rules. Most of the initials are of Wagner's types $\mathrm{Vb}$ and VIII.

107 Juan Vásquez, Agenda defunctorum (Sevilla: Martín de Montesdoca, 1556). See Wagner, Martín de Montesdoca, bibliografica critica, no. XXV.

108 Russell, 'Music in the House of the Third Duke of Béjar', 296-298.

109 Rees, The Requiem of Tomás Luis de Victoria, 81.

110 Wagner, Martín de Montesdoca, 31.

111 The sizes are as follows: Roman ( $2 \mathrm{~mm}$ high); Gothic ( $3 \mathrm{~mm} / 4 \mathrm{~mm}$ high), while the music type measures 12 / $8 \mathrm{~mm}$.

112 Both are illustrated in Wagner, Martin de Montesdoca, 10b and 10c along with the title-page, which shows the arms of Juan Bravo (Figure 10a), to whom the book is dedicated.

113 Wagner, Martín de Montesdoca, 26, 53-54; Norton, Printing in Spain, 28, 109.

114 Norton, A Descriptive Catalogue, 347-348.

115 Wagner, Martín de Montesdoca, 54-55.

116 Desiderius Erasmus, De octo orationis partium constructione (Osuna: Juan de León, 1551).

117 Gil, ‘Un español ante la Inquisición'. 
118 Vindel, Escudos y marcas, nos.185, 235. As printed on the title-page of the libro segundo of the Orphenica lyra, the Hercules mark is different from the mark shown in Vindel in a number of respects: the motto is printed under the mark in red ink rather than black, and the figure looks to the left not the right as elsewhere. For Montesdoca's second mark see also Wagner, Martin de Montesdoca, 47, illustration 3.

119 Interestingly, one early reader completed the text of the printer's mark in his copy of Fuentes, Summa de philosophia natural (Seville: Juan de León, 1547) now in Madrid, Biblioteca de la Real Academia Española, with the comment 'along with works' ('cum operibus').

120 WA 40.3: 352.

121 Juan Vásquez, Recopilacion de sonetos y villancicos a quarto y a cinco (Seville: Juan Guttierez, 1560). This dedication, to Gonzalo de Moscoso y Casceres, speaks appreciatively of both Francisco Guerrero and Cristóbal Morales as the 'light of music' ('luz de la música'). The unique copies, in the Biblioteca March in Palma de Mallorca, are bound together with copies of Guerrero, Sacrae cantiones (Seville: Martín de Montesdoca, 1555), Vásquez, Villancicos i canciones (Osuna: Juan de León), and the Septiesme livre de chansons a quatre parties (Louvain: Pierre Phalèse, 1562) in a contemporary blind-stamped leather binding. They are not recorded in Wilkinson, Libros ibericos.

122 Griffin, The Crombergers, 105-109.

\section{References}

Álvarez Márquez, Carmen. La impressión y el comercio de libro en la Sevilla del Quinientos. Seville: Secretariado de Publicaciones, Universidad de Sevilla, 2007.

Anglés, Higinio, and José Subirá. Catálogo musical de la Biblioteca Nacional de Madrid, II: Impresos: Libros litúrgicos y teóricos musicales. Barcelona: Instituto Español de Musicología, 1949.

Bordas, Cristina. 'The Double Harp in Spain from the 16th to the 18th Centuries'. Early Music 15 (1987): 148-163.

Braudel, Fernand. Civilization and Capitalism, 15th-18th Century. 3 vols. London: Collins, 1981-1984.

Brown, Howard M. Instrumental Music Printed before 1600: A Bibliography. Cambridge, MA: Harvard University Press, 1965.

Chaunu, Pierre. Séville et l'Atlantique aux XVI et XVII siècles. 2 vols. Paris: A. Colin, 1955-1956.

Civale, Gianclaudio. 'Domingo de Baltanás, monje solicitante en la encrucyada religiosa andaluza: confésion, inquisición y compañia de Jesús en la Sevilla del siglo de oro'. Hispania sacra 59 (2007): 197-241.

Cruikshank, Don W. 'Some Aspects of Spanish Book-Production in the Spanish Golden Age'. The Library 31 (1976): 1-19.

Domínguez Guzmán, Aurora. El libro sevillano durante la primera mitad del siglo XVI. Sevilla Diputación Provincial de Sevilla, 1975.

Fenlon, Iain. 'Jacques Moderne's Choirbooks and the Iberian Music Trade'. In French Renaissance Music and Beyond: Studies in Memory of Frank Dobbins, edited by Marie-Alexis Colin. Turnhout: Brepols, 2019, 218-232.

Freis, Wolfgang. 'Becoming a Theorist: The Growth of Juan Bermudo's Declaración de instrumentos musicales'. Revista de musicologia 28 (1995): 27-112.

Gemberro Ustárroz, Maria. 'Circulación de libros de música entre España y América (1492-1650: Notas para su estudio'. In Early Music Printing and Publishing in the Iberian World, edited by Iain Fenlon and Tess Knighton. Kassel: Reichenberger, 2006, 147-179.

Gestoso y Pérez, José. Noticias ineditas de impressores sevillanos. Seville: Gómez Hermanos, 1924.

Gil, Juan. ‘Un español ante la Inquisición romana: Francisco Mudarra'. In Scripturus vitam. Lateinische Biographie von der Antike bis in die Gegenwart. Festgabe für Walter Berschin zum 65. Geburtstag, edited by Dorothea Walz. Heidelberg: Mattes Verlag, 2002, 617-625. 
Giselbrecht, Elisabeth, and Elizabeth Savage. 'Printing Music: Technical Challenges and Synthesis, 1450-1530'. In Early Music Printing in German-Speaking Lands, edited by Andrea Lindmayr-Brandl, Elisabeth Giselbrecht and Grantley Mc Donald. London and New York: Routledge, 2018, 84-99.

Griffin, Clive. The Crombergers of Seville. The History of a Printing and Merchant Dynasty. Oxford: The Clarendon Press, 1988.

Griffin, Clive. Journeymen-Printers, Heresy, and the Inquisition in Sixteenth-Century Spain. Oxford: Oxford University Press, 2005.

Griffiths, John. 'Printing the Art of Orpheus: Vihuela Tablatures in Sixteenth-Century Spain'. In Early Music Printing and Publishing in the Iberian World, edited by Iain Fenlon and Tess Knighton. Kassel: Reichenberger, 2006, 181-214.

Griffiths, John. 'The Transmission of Secular Polyphony in Renaissance Spain: Esteban Daza and Rodrigo de Ceballos'. In Encomium musicae. Essays in Memory of Robert J. Snow, edited by David Crawford and G. Grayson Wagstaff. Hillsdale, NY: Pendragon Press, 2002, 321-340.

Hazañas y La Rua, Joaquín. La imprenta en Sevilla: ensayo de una historia de la tipografía sevillana y noticias de algunos de sus impresores desde la introducción del arte tipográfico en esta ciudad hasta el año de 1800. 2 vols. Seville: Imprenta de la Revista de Tribunales, 1892.

Ladero Quesada, Miguel Ánge. La ciudad medieval (1248-1492), Historia de Sevilla 2. 2nd ed. Seville: Secretariado de Publicaciones de la Universidad de Sevilla, 1980.

Lindmayr-Brandl, Andrea. 'Early Music Prints and New Technology: Variants and Variant Editions'. Fontes artis musicae 64 (2017): 244-260.

López-Vidriero, María L. 'The History of the Book in the Iberian Peninsula'. In The Oxford Companion to the Book, edited by Michael J. Suarez and H. Woudhuysen. 2 vols. Oxford: Oxford University Press, 2010, 1: 248-256.

Moll, Jaime. 'Gaspar Zapata, impresor sevillano condenado por la Inquisición en 1562'. Pliegos de bibliografía 7 (1999): 5-10.

Norton, Frederick J. A Descriptive Catalogue of Printing in Spain and Portugal 1501-1520. Cambridge: Cambridge University Press, 1978.

Norton, Frederick J. Printing in Spain 1501-1520. Cambridge: Cambridge University Press, 1966.

Otaola González, Paloma. La pensée musicale espagnole à la Renaissance: Héritage antique et tradition médievale. Paris: L’Harmattan, 2008.

Palau y Dulcet, Antonio. Manual del librero hispano-americano. Bibliografía general española e hispano-americana desde la invención de la imprenta hasta nuestros tiempos con el valor commercial de los impresos descritos. 2nd ed. 28 vols. Barcelona: Libreria Anticuaria de A. Palau, 1948-1977.

Peeter-Fontainas, Jean. Bibliographie des impressions espagnoles des Pays-Bas Méridionaux. 2 vols. Nieuwkoop: B. De Graaf, 1965.

Péligry, Christian. 'Les editeurs Lyonnais et le marché espagnol aux XVI et $\mathrm{XVII}{ }^{\mathrm{e}}$ siècles'. In Livre et lecteur en Espagne et en France sous l'Ancien Régime. Colloque de la casa de Velázquez, Madrid, 17-19 Novembre 1980. Paris: Association pour la diffusion de la pensée française, 1981, 85-95.

Pettas, William. A Sixteenth-Century Spanish Bookstore. Philadelphia, PA: American Philosophical Society, 1995.

Pike, Ruth. Enterprise and Adventure: The Genoese in Seville and the Opening of the New World. Ithaca, NY: Cornell University Press, 1966.

Rees, Owen, The Requiem of Tomás Luis de Victoria. Cambridge: Cambridge University Press, 2019.

Restrepo, Margarita. 'German-Speaking Music Printers and the Development of Music Printing in Spain (1485-1505)'. In Early Music Printing in German-Speaking Lands, edited by Andrea 
Lindmayr-Brandl, Elisabeth Giselbrecht and Grantley McDonald. London and New York: Routledge, 2018, 46-63.

Roa Alonso, Francisco J. 'Alonso Mudarra, vihuelista en la casa del Infantado y canónigo en la Catedral de Sevilla'. 2 vols. PhD dissertation, Universidad Complutense de Madrid, 2015.

Roldan-Figueroa, Rady. The Ascetic Spirituality of Juan de Ávila (1499-1569). Leiden: Brill, 2010.

Ros-Fábregas, Emilio. 'Libros de música en bibliotecas españolas en el siglo XVI'. Pliegos de bibliofilia 17 (2002): 17-54.

Russell, Eleonor. 'Music in the House of the Third Duke of Béjar, ca. 1520-1544'. In Encomium musicae. Essays in Memory of Robert J. Snow, edited by David Crawford and G. Grayson Wagstaff. Hillsdale, NY: Pendragon Press, 2002, 285-304.

Russell, Eleonor, ed. Juan Vásquez: Villancicos i canciones. Madison: A-R Editions, 1995.

Serrera Contreras, Ramón María. 'La Casa de la Contratación en el Alcázar de Sevilla (1503-1717)'. Boletín de la Real Academia Sevillana de Buenas Letras 36 (2008): 141-176.

Stevenson, Robert. Juan Bermudo. The Hague: Martínus Nijhoff, 1960.

Valls i Subirà, Oriol. La historia del papel en España siglos XV-XVI. 3 vols. Madrid: Empresas Nacional de Celulosas, 1978-1982.

Vindel, Francisco. Escudos y marcas de impressores y libreros en España durante los siglos XV a XIX (14851850). 2 vols. Barcelona: Orbis, 1942.

Wagner, Klaus. El doctor Constantino Ponce de la Fuente: el hombre y su biblioteca. Sevilla: Diputación Provincial de Sevilla, 1980.

Wagner, Klaus. Martín de Montesdoca y su prensa: contribución al studio de la imprenta y de la bibliografia sevillana de siglo XVI. Seville: Universidad de Sevilla, 1982.

Wagner, Klaus. 'A proposito de la biblioteca de Jerónimo de Chaves, catedrático de cosmografia de la Casa de Contratación y el paradero de algunos de sus libros'. In La cultura del libro en la edad moderna: Andalucia y America, edited by Manuel Peña Díaz et al. Córdoba: Servicio de Publicaciones de la Universidad de Sevilla, 2001, 187-231.

Wilkinson, Alexander, ed. Iberian Books: Books Published in Spanish or Portuguese or on the Iberian Peninsula before 1601 / Libros ibéricos: Libros publicados en español o portugués en la Península Ibérica antes de 1601. Leiden and Boston, MA: Brill, 2010. 